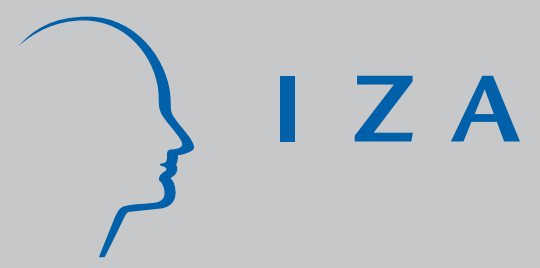

IZA DP No. 263

Children and Career Interruptions: The Family Gap in Denmark

Nabanita Datta Gupta

Nina Smith

February 2001 


\title{
Children and Career Interruptions: The Family Gap in Denmark
}

\author{
Nabanita Datta Gupta \\ CIM, CLS and Department of Economics, Aarhus School of Business \\ Nina Smith \\ CIM, CLS and Department of Economics, Aarhus School of Business, \\ and IZA, Bonn
}

Discussion Paper No. 263

February 2001

\author{
IZA \\ P.O. Box 7240 \\ D-53072 Bonn \\ Germany \\ Tel.: $+49-228-3894-0$ \\ Fax: +49-228-3894-210 \\ Email: iza@iza.org
}

This Discussion Paper is issued within the framework of IZA's research area The Future of Work. Any opinions expressed here are those of the author(s) and not those of the institute. Research disseminated by IZA may include views on policy, but the institute itself takes no institutional policy positions.

The Institute for the Study of Labor (IZA) in Bonn is a local and virtual international research center and a place of communication between science, politics and business. IZA is an independent, nonprofit limited liability company (Gesellschaft mit beschränkter Haftung) supported by the Deutsche Post AG. The center is associated with the University of Bonn and offers a stimulating research environment through its research networks, research support, and visitors and doctoral programs. IZA engages in (i) original and internationally competitive research in all fields of labor economics, (ii) development of policy concepts, and (iii) dissemination of research results and concepts to the interested public. The current research program deals with (1) mobility and flexibility of labor markets, (2) internationalization of labor markets and European integration, (3) the welfare state and labor markets, (4) labor markets in transition, (5) the future of work, (6) project evaluation and (7) general labor economics.

IZA Discussion Papers often represent preliminary work and are circulated to encourage discussion. Citation of such a paper should account for its provisional character. 
IZA Discussion Paper No. 263

February 2001

\title{
ABSTRACT \\ Children and Career Interruptions: The Family Gap in Denmark"
}

The effect of children and career interruptions on the family gap is analysed based on Danish longitudinal data covering the years 1980-1995. The estimated model controls for unobserved time-constant heterogeneity. The results show that when controlling for unobserved heterogeneity, the negative effect of children on mothers' wages disappears. The main effect of children seems to be loss of human capital accumulation during childbirth periods. Beside this, there is no indication that children have long-term effects on the earnings potential of their mothers, holding experience constant.

JEL Classification: J9

Keywords: Children, career interruptions, family gap, unobserved heterogeneity

\author{
Nina Smith \\ Aarhus School of Business \\ Department of Economics and CIM \\ Fuglesangs Alle 20 \\ DK-8210 Aarhus V \\ Tel.: +4589486413 \\ Fax: +458615 5175 \\ Email: nina@asb.dk or nina@cls.dk
}

\footnotetext{
* This project has been supported financially by the Danish Research Agency (the FREJA grant). The authors want to thank two anonymous referees for very helpful comments on a former version of the paper and Kristina Venø Rostbo who has done most of the computational work behind this paper. The paper has been presented at a workshop in Stockholm 9-10 June, 1999, supported by the Social Research Councils in the UK and Scandinavia.
} 


\section{Introduction}

Traditionally, the gender wage gap has been explained by gender differences in the level of human capital, discriminatory forces in the labour market and the importance of family responsibilities which typically reduce the earnings capacity of women but increase men's wages. During recent decades, the gender wage gap has been decreasing in many countries, but a tendency of stagnation of this process appears in some countries. This may seem paradoxical. In many countries, equal pay legislation was put into force in the 1970s and 1980s. At the same time, women's educational attainment has increased dramatically in most countries. Today, the educational level of women is close to that of men in many countries. Further, the increased participation rate of women has improved the average level of female on-the-job training and labour market experience. Therefore, there is an increasing focus on the effects of family responsibilities on women's wages as one of the explanations of the apparent paradox of stagnating gender wage equalization.

In many empirical analyses, it has been found that the presence or the number of children in the household has a negative effect on women's wages, see Korenman and Neumark (1991, 1992), Waldfogel (1998a,b). Being married also tends to reduce the female earnings capacity while a positive marriage premium often is found for males. The effect of children on earnings capacity may reflect a reduced work intensity of mothers after childbirth due to responsibilities at home. It may also reflect previous periods out of the labour market if the included measures of experience do not explicitly account for career interruption periods. In a number of empirical studies, it is found that periods of career interruptions due to childbirth and childrearing reduce human capital and earnings capacity of the mothers, see for instance Ruhm (1998) for a recent study. However, the findings in this area are not unambiguous. For instance, Albrecht et al. (1999) and Waldfogel (1998a) find no negative effect on subsequent earnings for women entering into formal maternal leave schemes. For the UK, Joshi et al. (1999) also find that mothers do not have lower wages than women without children when the model controls for the generally lower wages for part-timers and the possible endogeneity of children.

Previous Danish results do not entirely confirm the results found in the international literature. Rosholm and Smith (1996) and Naur and Smith (1997) do not find any evidence of children having a negative effect on women's wages or on the gender wage gap. However, Naur and Smith (1997) find that married or cohabiting men obtain a 'marriage premium' which is significantly greater than zero. A number of studies have focussed on other explanations of the stagnating Danish gender wage gap during the 1980s, see Datta Gupta et al. (1998, 1999). The main explanations have been the slow growth of public sector wages and the wage formation process with more decentralized 
wage bargaining. ${ }^{1}$

In this paper, we analyse the effect of children and career interruptions on women's earnings capacity. First, we analyse whether the results concerning the effects of children are sensitive to the econometric approach applied. Second, we explore how earnings profiles are affected by years out of the labour force during childbirth periods. Finally, we estimate the effects of the number and timing of children on the earnings capacity of women. The data set is a $0.5 \%$ representative panel sample of the Danish population covering each of the years 1980-1995. Thus, in contrast to most other studies, we are able to control for unobserved time constant heterogeneity among women which may be a very important problem encountered in earlier cross-section analyses of career interruptions and children's effect on the earnings capacity of their parents. The results show that when controlling for unobserved heterogeneity, the negative effect of children on mothers' wages disappears. The main effect of children seems to be loss of human capital accumulation during childbirth periods. Beside this, there is no indication that children have long-term effects on the earnings potential of their mothers, holding experience constant.

\section{Theoretical considerations}

In many countries, the gender wage gap decreased substantially in the 1970s and 1980s. One of the main reasons behind this development has been women's increasing relative human capital accumulation due to formal education and job experience during the latest decades. However, in some European countries, for instance Denmark, Sweden and the UK, the equalization of the gender wage gap seems to have stagnated, see Rosholm and Smith (1996) and Datta Gupta et al. (1999). One of the explanations of the observed stagnation of the gender wage gap has been the fact that women, despite their increased formal human capital qualifications, still tend to have long career interruptions due to family reasons, mainly for childbearing and childrearing. Further, the extension of maternal and parental leave schemes in many countries may have adversely affected the position of women, because the length of average periods out of the labour market increases and because the leave schemes are used much more by mothers than by fathers.

Traditional human capital theory offers at least three reasons for the connection between women's career interruptions and the increase in the earnings gap between men and women, see for instance

\footnotetext{
${ }^{1}$ Another explanation may be the introduction and extension of maternal and parental leave schemes in the mid 1980s and the early 1990s, particularly the major extension in 1994 introducing a new parental leave over and above the existing maternal and paternal leaves. These leave schemes may have unanticipated negative effects on the gender wage gap if women are considered less stable workers because they use the schemes much more than men. Thus, we might expect the results concerning the effect of children on the earnings capacity of the mothers and more general, the gender wage gap, to be affected by these leave schemes, but our data do not span a sufficiently long period in the 1990 s to be able to uncover the effects of parental leave legislation on wages.
} 
Mincer and Polachek (1974). First of all, during periods out of the labour market, the individual does not accumulate human capital. Second, there may be depreciations of human capital (atrophy) in periods out the labour market because educational and job-related qualifications become obsolete or are forgotten. Third, women who expect to have career interruptions may choose jobs with less on-the-job training if the employee pays the majority of the costs of this jobtraining by lowering wages. Alternatively, if the firm pays the job training, it may be less willing to assign women to jobs with a high level of job training, because it expects women to be out of the labour market for longer periods than men, or women to have higher turnover. Thus, it is more difficult for firms to recoup the investments in job training for women than for men. A number of empirical studies have tested these effects and in general, they confirm that periods out of the labour market have negative effects on the earnings capacity, see the survey in Ruhm (1998).

Traditional human capital theory says that if a woman becomes a non-participant during the 'childbirth period', she does not accumulate job training and experience, and that she may even be exposed to atrophy. After the period of fertility is completed, she may return to the labour market and start accumulating experience. If it is easy to regain lost human capital, there may be a catching-up effect and a steeper wage profile after childbirth. If mothers who have been out of the labour market are typically assigned to jobs with lesser promotion prospects, they will experience flatter career profiles. However, if childbirth and career interruptions are already expected at the start of the female career, potential mothers may themselves select jobs with a low level of job training, but possibly with higher starting wages. If this is the case, the profile will be flatter, but the starting wage when entering the labour market will typically be higher than that of women (or men) who do not expect periods out of the labour market.

However, these basic human capital results can hardly explain the entire effect of career interruptions on subsequent earnings. Waldfogel (1998a) argues that maternal leave schemes tend to protect women from losing job tenure and tenure-related benefits during their childbirth periods. ${ }^{2}$ Further, Waldfogel (1998a, p. 512) claims that maternity leave arrangements may have positive effects on women's wages: "To the extent that maternity leave allows women to benefit from pre-birth job tenure, maintain good job matches, and continue to progress up a firm's career ladder, extending rights may have a positive effect on pay". She also argues that firms may use generous maternity leave schemes as a fringe benefit with which they attract the most qualified women, reduce turnover among women etc. If this effect is widespread, it tends to give a positive

\footnotetext{
${ }^{2}$ It is usually assumed that maternal leave schemes have positive employment effects for women because they facilitate a more firm labour force attachment of mothers compared to regimes without maternity leave schemes, see Ruhm (1998). This effect may be one of the main explanations of the high labour force participation rates in the Scandinavian countries.
} 
relationship between female wages and the take-up of maternal leave schemes. Waldfogel's empirical analyses for the US and UK confirm her hypotheses. The effect of children is strongly negative on mothers' wages, but there is a large positive premium on wages for mothers who are covered by and actually use the maternity leave schemes.

Albrecht et al. (1999) find no effect on subsequent earnings for Swedish women who enter formal maternal leave schemes while the effect for (the relatively few) men is significantly negative. They explain the lack of a negative effect of career interruptions on the subsequent wages of Swedish women by the fact that the Swedish parental leave system is sufficiently generous so that almost all women take a substantial amount of leave. This results in less variation in the length of the periods out of the labour market (compared to for instance US women or Swedish men). Thus, there is less potential in Sweden for leave taking behaviour to signal anything about a woman's 'type' with respect to commitment to work and productivity. These results are confirmed for the Danish labour market in Rosholm and Smith (1996) who find no significantly negative effects of children on women's wages .

A complementary explanation of the apparently small or non-existing negative effects of maternal leave schemes on mothers' wages in the Scandinavian countries may be statistical discrimination, see for instance Rosenfeld and Kalleberg (1991). If maternal leave schemes are used by almost all mothers, as is the case in countries with generous and universal leave schemes, we may not expect to find large effects of children and maternal leave periods on the subsequent wages of the individual mothers because employers expect all women to have children and to enter into maternal leave schemes. Thus, it may be rational for the employer to assign young women to flatter career profiles with less promotion, less job-training and smaller wage increases. On average, young women are expected to have one or two children and to take the full maternal leave period allowed. The longer the formal maternal or parental leave schemes and the larger the difference between men and women's use of these schemes, the larger is the potential for statistical discrimination. This theory complements the signalling theory in the sense that even though the individual woman does not signal low productivity by taking up a maternal leave scheme when the scheme has close to $100 \%$ coverage, maternal leave schemes are expected to have a negative effect on all women, irrespective of their actual behaviour with respect to career interruptions. Thus, we should expect that an increase of the generosity of these schemes has an effect on overall female wages, but not on the relative wages of women who have children and pick up maternal leave compared to women without children. ${ }^{3}$ If the fraction of men using parental leave schemes increases or if paternal leave schemes are introduced or extended, we should expect statistical

\footnotetext{
${ }^{3}$ There may still be a 'traditional human capital' effect on the mothers' wages due to loss of accumulation of experience and job tenure during maternal leave periods.
} 
discrimination against women to decrease.

Thus, the universal character of maternal leave schemes in Denmark and other Scandinavian countries may modify the positive effects discussed by Waldfogel (1998a). When leave schemes cover the whole labour market, it is not a parameter that firms can use to attract the best workers. The women entering the schemes are not a selected group of women who on average have better qualifications than those without access to maternity leave. Therefore, we expect the effect of the Danish universal maternity leave schemes to influence the wages of all young women who are potential mothers while the effects on the individual mothers are expected to be smaller than in countries where the coverage of maternal leave schemes is not universal. ${ }^{4}$

Other modifications to the effects discussed by Waldfogel are country differences with respect to job flexibility, job tenure and the amount of tenure-related benefits and job protection, see OECD (1996). Denmark has about the same job mobility as the US when measured by the average number of years spent at the same employer, see OECD (1996). There are very few tenure-related benefits and there is very little job protection, compared to most other European countries. ${ }^{5}$ Thus, the expected loss from job interruptions due to childbirth and long maternal leave periods is not as large in Denmark as in many other countries.

\section{Empirical model}

The data used in this study is a panel sample of men and women observed during each of the years 1980-1995. The sample is unbalanced and thus, the individuals are not necessarily observed during all 16 years of the sample period. We use a panel estimator allowing us to take into account the effect of unobserved time constant heterogeneity which may be rather important when analyzing gender differences in the effect of children on wages. For example, there may be differences in (time-constant) unobserved preferences for home production which tend to increase the number of children born, and which tend to reduce the woman's investments in earnings capacity after formal schooling. If there is no control for this type of unobserved heterogeneity, the simple crosssection ordinary least square estimators of the child variables tend to be biased downwards, i.e. to be more negative than the panel estimators.

\footnotetext{
${ }^{4}$ See Datta Gupta and Smith (2000) for a more detailed description of the Danish leave schemes. On average, Danish mothers spend 28 weeks on maternity leave for each child born, while the fathers spend 1 week. After 1994, when a new parental leave scheme was introduced, these figures increased to 50 weeks for mothers and 3 weeks for fathers.

${ }^{5}$ The explanation of this evidence is that to a large degree the Danish welfare schemes have overtaken the burden from the firms of job protection etc. Thus, sickness and unemployment payments are relatively generous with a close to $100 \%$ coverage for those exposed to these events, and eligibility rules are generous.
} 
Instead, we estimate human capital functions where age and number of children, periods of nonparticipation and accumulated employment experience and timing of accumulation of experience before and after the childbirth period are included in different specifications.

The basic model can be formulated as:

$$
\ln \mathrm{W}_{\mathrm{it}}=\beta_{0}+\mathbf{X}_{\mathrm{it}} \boldsymbol{\beta}+\left(\alpha_{\mathrm{i}}+\epsilon_{\mathrm{it}}\right) .
$$

$\mathbf{X}_{\mathrm{it}}$ is a vector of explanatory variables. The subscripts $i$ and $t$ index the individual and time, respectively. $\alpha_{\mathrm{i}}$ is the unobserved heterogeneity term, assumed to be individual-specific, timeinvariant and $\operatorname{Nid}\left(0, \sigma_{\alpha}^{2}\right)$, and $\epsilon_{\mathrm{it}}$ is an error component, $\operatorname{Nid}\left(0, \sigma_{\epsilon}^{2}\right)$.

If the individual-specific error term is assumed to be random, the model may be estimated by a random effects estimator. Provided that $E\left(\alpha_{\mathrm{i}} \mid \mathbf{X}_{\mathrm{it}}\right)=0$, this is a consistent and efficient estimator of (1). We use a GEE (Generalized Estimating Equation) estimator which is an iterative maximum-likelihood estimator. The GEE estimator gives robust estimates of the covariance matrix of the estimated $\boldsymbol{\beta}$, i.e. the GEE estimator gives consistent estimates of the covariance matrix even if the working covariance matrix is mis-specified. ${ }^{6}$

If the model includes variables correlated with the $\alpha_{\mathrm{i}}$, the random effects estimator gives inconsistent estimates. As an alternative, we present results from a fixed effects estimation where all variables in (1) are transformed into deviations from individual means. The fixed effects estimator provides consistent but inefficient estimates, conditional on the distribution of the fixed effect. Since the fixed effects estimates do not deviate much from the more efficient random effects estimates, we prefer to use the random effects estimator in most of the presented models. ${ }^{7}$

In order to correct for the self-selectivity effect due to missing wage information of individuals who are non-participants, we include the estimated value of the inverse of Mill's ratio ('lambda') as an extra explanatory variable, see Heckman (1979). Lambda is based on a probit-estimation of the probability of participation on the full sample of participants and non-participants. The probit

\footnotetext{
${ }^{6}$ The model is estimated by SAS, using the GENMOD procedure. The likelihood function is maximized by a ridgestabilized Newton-Raphson algorithm. The GEE procedure in SAS allows to estimate the model in (1) using different specifications of the covariance matrix. The results from the random effects specification have been compared to the results using an unstructured covariance matrix. The results from the unstructured specification were very close to the results from the random effects specification. The procedure is described in SAS/STAT Software (1997): Changes and Enhancement through Release 6.12.

${ }^{7}$ However, a Hausman test on the assumption $E\left(\alpha_{\mathrm{i}} \mid \mathbf{X}_{\mathrm{it}}\right)=0$ rejected the assumption. The same result was found in Rosholm and Smith (1996) who used the same sample for the period 1980-90.
} 
model and the lambda variable are estimated separately for each year (cross-section estimates). ${ }^{8}$ The included variables in the probit estimation are partly the same as in the wage functions. Identification is obtained by including occupational categories in the wage function but not in the probit function, while the probit function includes the extra variables household wealth, household non-wage income and ownership of house or apartment. Experiments with other exclusion restrictions showed that the results are fairly robust with respect to choice of excluded variables.

A major problem in most analyses of the effects of children on the economic behaviour and outcomes of household members is that the number and age of children may be endogenous to the model, see Browning (1992) and Joshi et al. (1999). In our case, focusing on mothers' wages, women with low earnings capacity may choose to have more children, probably implying that the estimates of the influence of children are too negative. The problem might be handled by instrumenting the child variables or by estimating separate wage functions for mothers and nonmothers and controlling for the selection into the group of mothers and non-mothers as in Joshi et al. (1999). However, the register-based sample does not include variables that can be used as valid instruments, i.e. variables affecting the choice of having children but not the human capital and earnings capacity of the women. ${ }^{9}$

\section{Data}

The sample used in this study is a sub-sample of a Danish longitudinal database which is a representative 5\% sample of the Danish population. A description of the master sample which stems from administrative registers is given in Westergård-Nielsen (1988). The master sample was selected in 1980 as a random sample of the Danish population aged 18 and upwards. From the master sample, a representative sample consisting of $0.5 \%$ of the population aged 18 or more and born after 1940 (aged 40 years in 1980) is selected. The reason for the latter restriction is that we do not have complete information on the number of children born of individuals older than 40 years in 1980. The selected individuals are observed during the period 1980-1995. The original (master) sample is a representative sample of the population and new birth cohorts enter the master sample. We allow younger birth cohorts during each of the years after 1980 to enter the sample used in this study in order to capture potential effects of maternal and parental leave

\footnotetext{
${ }^{8}$ This may be criticized because optimally, the selection process should be estimated by a panel data sample selection estimator in line with Verbeek and Nijman(1992) and Vella (1998) among others. Since we exclude, due to data problems, women with less than 1,000 hours employment annually, the left-hand side variable in the probit model is whether the individual is included in the wage function or not.

${ }^{9}$ We expect this problem to be smaller than in cross-section estimates because time constant unobserved heterogeneity is controlled for in the panel estimates. However, there may also exist time variant heterogeneity which we do not control for and which may give rise to a possibly negative bias in the estimates of the child parameters.
} 
schemes on younger birth cohorts. Thus, the 'gross sample' selected for this study is representative for the population aged 40 years or less in 1980 and representative for the population aged 55 years or less in 1995. Since the selected individuals in the 'gross sample' on average become older when time goes by, it is necessary to restrict the sample to the same age categories when comparing for instance the effects of children in 1980 with the effects in 1995 . For these crosssection comparisons, we use a smaller sample of individuals aged 18-40 years in each of the years concerned. In total, the selected sample contains 28,578 female and 35,078 male observations. These figures correspond to 1,291 women and 1,885 men in 1980 and 2,328 women and 2,655 men in 1995.

The hourly wage rate is not observed directly but is constructed as annual wage income divided by number of working hours, which is calculated from the register on supplementary pension payment (ATP). ${ }^{10}$ The wage rate is deflated by the consumer price index $(1980=100)$. Since we are only able to calculate hourly wage rates for individuals employed as wage earners, i.e. manual and non-manual workers, we exclude self-employed persons. In the estimations of wage functions, we only include individuals with an annual employment of more than 1,000 hours because earlier studies based on the Danish longitudinal data base have shown that there are measurement errors for part-time workers, see Datta Gupta et al. (1999). ${ }^{11}$ The potential sample selection problems due to this sample exclusion rule are handled by including the estimated value of the inverse Mill's ratio $(\lambda)$ as an extra explanatory variable, in line with Heckman (1979). A probit model is estimated in order to calculate the estimated value of $\lambda$. The explanatory variables in the probit estimation are indicators for ownership of house or apartment, non-wage income, wealth and child variables.

We do not have exact information on periods out of the labour force before 1980 and therefore, we are not able to construct exact employment spells and spells of non-participation. Thus, we are

\footnotetext{
${ }^{10}$ Each wage earner aged 16-66 years who is employed by an employer for more than 9 hours a week is obliged by law to contribute to the ATP scheme. The contribution to ATP depends only on the degree of employment in each week. The share follows a stepwise function, where 0-9 hours/week implies 0 ATP contribution, 10-19 hours/week implies $1 / 3$ of the full contribution, 20-29 hours/week implies $2 / 3$ of the full contribution and more than 30 hours a week implies full ATP contribution. The hourly wage is calculated using this information together with information on standard working hours. Overtime work does not usually imply higher ATP contributions implying that groups with extensive overtime work will have an upward biased hourly wage rate. For more detailed information, see Westergård-Nielsen (1988).

${ }^{11}$ Thus, we ignore the potential effect of part-time employment on the gender and family wage gap which has shown to be very important in other countries, see for instance Joshi et al. (1999). For Denmark, empirical studies show that this is not a very important issue when explaining gender wage differentials because part-timers tend to have about the same wage functions as full-timers, see Naur et al. (1994). Further, the female part-time employment rate has been steadily declining during the latest two decades, from about $40 \%$ in the early 1980 s to less than $20 \%$ in 1997.
} 
not able to test whether the exact timing of childbirth or the length and frequency of career interruptions are important for the earnings capacity of mothers. But for each individual in the sample, we have exact information on the accumulated employment experience since the start of her or his labour market career. The experience variable measures the number of years and months in which the individual has been employed as a wage earner. The information on accumulated experience comes from the ATP register which gives a relatively precise picture of employment since the start of the career. Periods out of the labour market or periods of part-time employment or unemployment imply that no experience or less than full experience is accumulated. For the youngest cohorts of men and women born after 1960, it is possible to split the accumulated experience into experience obtained before birth of first child, during the childbirth period and after birth of last child. This information is used in some of the estimations in order to test more detailed models relating to the coefficients to experience variables, for instance to test the hypothesis of whether women seem to catch-up with respect to remuneration of human capital after ending the childbirth period.

The sample contains information on type of education. However, in the estimation of human capital functions we only use the number of years of formal education beyond the compulsory school age as an explanatory variable. Marital status is measured by two indicator variables: "Married" takes the value 1 if the person is legally married. "Cohabitant" takes the value 1 if the person is living with a partner but not legally married. Thus, the excluded category is "single persons" who are neither married nor cohabiting. In most of the estimations presented below, the number of children is indicated by the three dummy variables ' 1 child', '2 or more children' and 'youngest child 0 - 2 years old'. ${ }^{12}$ We also include number of children and the squared value in order to try different specifications of child variables.

\footnotetext{
12 The number of children includes children aged 18 or more, contrary to earlier analyses on the Danish longitudinal data base including annual information on number of children in different age categories, 0-2 years, 3-6 years, 7-14 years and 0-17 years. Based on this information for all of the years 1979-1990, we have estimated the number of children born in the families. For the oldest cohort, we may still have underestimated the number of children if the individuals had children aged 18 or more before 1979 .
} 
Table 1. Average sample values for selected human capital variables and hourly wage rates (DKK) by number of children. Cross-section samples of men and women aged 18-40 years in 1980 and 1995. Male-female ratios in parentheses.

\begin{tabular}{|c|c|c|c|c|c|c|}
\hline & & & 0 children & 1 child & $\begin{array}{c}2 \text { or more } \\
\text { children }\end{array}$ & All \\
\hline \multirow[t]{12}{*}{1980} & \multirow{3}{*}{$\begin{array}{l}\text { Actual experience, } \\
\text { years: }\end{array}$} & Men & 5.97 & 8.42 & 10.29 & 7.96 \\
\hline & & Women & 4.82 & 7.33 & 7.39 & 6.52 \\
\hline & & & $(1.24)$ & $(1.15)$ & (1.39) & $(1.22)$ \\
\hline & \multirow{3}{*}{$\begin{array}{l}\text { Years out of the } \\
\text { labour market: }\end{array}$} & Men & 3.14 & 3.53 & 4.39 & 3.65 \\
\hline & & Women & 2.55 & 4.73 & 7.17 & 5.06 \\
\hline & & & (1.23) & $(0.75)$ & $(0.61)$ & $(0.72)$ \\
\hline & \multirow{3}{*}{$\begin{array}{l}\text { Length of educa- } \\
\text { tion, years }\end{array}$} & Men & 2.05 & 2.65 & 2.75 & 2.41 \\
\hline & & Women & 1.95 & 2.13 & 2.25 & 2.13 \\
\hline & & & (1.05) & $(1.24)$ & $(1.22)$ & (1.13) \\
\hline & \multirow{3}{*}{$\begin{array}{l}\text { Hourly wage rate, } \\
1980 \text { prices, DKK: }\end{array}$} & Men & 61.19 & 66.56 & 70.60 & 65.64 \\
\hline & & Women & 50.93 & 52.88 & 50.96 & 51.43 \\
\hline & & & $(1.20)$ & $(1.26)$ & (1.39) & $(1.28)$ \\
\hline \multirow[t]{12}{*}{1995} & \multirow{3}{*}{$\begin{array}{l}\text { Actual experience, } \\
\text { years: }\end{array}$} & Men & 6.41 & 11.11 & 12.82 & 8.82 \\
\hline & & Women & 5.48 & 8.88 & 10.41 & 8.08 \\
\hline & & & (1.17) & $(1.25)$ & (1.23) & $(1.09)$ \\
\hline & \multirow{3}{*}{$\begin{array}{l}\text { Years out of the } \\
\text { labour market: }\end{array}$} & Men & 3.35 & 3.86 & 3.64 & 3.50 \\
\hline & & Women & 2.93 & 4.26 & 5.26 & 4.10 \\
\hline & & & (1.14) & $(0.91)$ & (0.69) & $(0.85)$ \\
\hline & \multirow{3}{*}{$\begin{array}{l}\text { Length of educa- } \\
\text { tion, years }\end{array}$} & Men & 2.02 & 2.64 & 2.82 & 2.33 \\
\hline & & Women & 2.77 & 2.99 & 2.92 & 2.87 \\
\hline & & & $(0.73)$ & $(0.88)$ & $(0.97)$ & $(0.81)$ \\
\hline & \multirow{3}{*}{$\begin{array}{l}\text { Hourly wage rate, } \\
1980 \text { prices, DKK: }\end{array}$} & Men & 63.55 & 77.85 & 78.30 & 70.01 \\
\hline & & Women & 56.30 & 60.71 & 59.54 & 58.46 \\
\hline & & & (1.13) & $(1.28)$ & (1.32) & $(1.20)$ \\
\hline
\end{tabular}

Note: The sample means refer to the sample used in the wage regressions presented below. Thus, an individual is only included in the mean if he/she was employed for more than 1,000 hours during the year.

In the Appendix, Table A1, the sample means for the pooled sample over the period 1980-1995 and for the years 1980 and 1995 are shown. Table 1 shows average actual experience, years out of labour market, length of education and hourly wage rates distributed by number of children for the first and last year of the sample period 1980-1995. In order to ensure comparability between the two years, 1980 and 1995, for both years we have only selected individuals from the age group 18 - 40 in Table 1. The ratio of average male to female experience decreases between 1980 and 1995. Columns 1-3 in Table 1 show that this ratio decreases for individuals with 0 or more than 1 child. Part of the decrease between 1980 and 1995 in the ratio of male to female actual 
experience is due to shorter non-experience periods for women with children in 1995 compared to 1980 . The average number of years out of the labour market for women with 2 or more children was 7.2 years in 1980 and 5.3 years in 1995. Another potential explanation of the changes between 1980 and 1995 might be age composition effects, but since Danish women on average tend to give birth to their first child at a steadily higher age, this does not explain the evidence in Table 1. In 1980, women were still lagging behind men with respect to educational attainment, especially women with children. This pattern has changed in 1995 where mothers as well as non-mothers aged less than 40 have more years of education than men. Finally, the average aggregate ratio of male to female hourly wage rates has decreased between 1980 and 1995 from 1.28 to 1.20, mainly due to a reduction of the wage ratio for the group without children and for women with 2 or more children. However, looking at the rough wage figures, Table 1 indicates that the gender wage gap tends to increase with number of children. This is also the case in 1995, despite the changes in the variables representing average experience and years out of the labour market.

\section{Estimation results}

In this section, we present results from estimating a number of human capital models where variables representing children and career interruptions are entered in the models in different ways in order to test a number of hypotheses on the influence of these variables on the earnings capacity of mothers. In some of the analyses, we include results for analogue models of men's wage functions in order to compare the effects of children on both sexes and the potential effects on the gender wage gap.

The first hypothesis studied is the sensitivity of the estimators applied. Is it important to control for unobserved individual heterogeneity and self-selectivity? This is analysed by comparing pooled OLS estimations with and without corrections for self-selection and panel data estimators. Table 2 shows the results from applying four alternative estimators on the preferred wage function. If there are unobserved variables affecting earnings capacity and which are correlated with the number of children, the LS estimates will be inconsistent. For men, the differences between the estimates of the child coefficients are minor. However, for women the significantly negative effect of children and marriage in the OLS and LS estimates disappears when a panel data estimator is used. The panel data estimators (fixed and random effects) control for time-constant unobservables. The fixed effects estimator is more robust than the random effect estimator in the sense that the estimates are consistent even if the unobserved time constant variables correlate with the included variables. But the fixed effects estimator is extremely inefficient if there are variables varying only very little over time such as marriage and education. This does not hold for the random effects estimator. Comparing the estimates from the two panel estimators, we do not find a large difference between the two estimators, except for a few fairly time-invariant variables. In 
the subsequent tables, we only show the results from applying the random effects estimator.

We also analyse whether number of children or the mere existence of one or more children matters for earnings capacity. Table A2 in the Appendix shows the results from estimating the random effects model with different specifications of the child variables: A model with a variable for number of children and the square of this variable, a model with 2 indicators for number of children and a model including an indicator for having very young children aged 0-2 years. In general, the coefficients to the child variables are insignificant for women, irrespective of specification and thus, the results shown in Table 2 are not sensitive to the choice of specification. In the subsequent estimations, we therefore prefer the model including two indicators (for 1 child and 2 or more children) because it is more flexible than the model with the number of children. The indicators for young children aged 0-2 years are all insignificant. Thus, we conclude that when controlling for other observed background variables, including labour market experience and unobserved time constant heterogeneity, having children does not seem to give lower wages for mothers compared to women with no children.

Another question is whether children have a direct wage effect when the model explicitly controls for missing human capital accumulation due to periods out of the labour market. This is analysed in Table 3, where Models 1 and 2 include two new variables, representing the number of years spent out of the labour market either as a non-participating housewife or as unemployed, as well as the square value of this variable. The results from Model 1 show no indication of atrophy during periods out of the labour market in the sense of a reduction in earnings capacity. This picture does not change in Model 2 where the child variables are excluded from the model in order to put as much weight as possible on the 'non-experience' variables. Thus, we conclude that career interruptions due to childbirth or unemployment periods do not affect the earnings capacity of women negatively, but compared to working women without employment interruptions, women without employment do not accumulate human capital and thus, they do not increase their earnings potential during periods out of employment. 
Table 2. Alternative estimators of log hourly wage. 1980-1995. (Standard errors in parentheses)

\begin{tabular}{|c|c|c|c|c|c|c|c|c|}
\hline & \multicolumn{4}{|c|}{ Men } & \multicolumn{4}{|c|}{ Women } \\
\hline & $\mathrm{OLS}^{1}$ & $\begin{array}{l}\text { LS (self-sel. } \\
\text { Corr.) }^{1}\end{array}$ & $\begin{array}{l}\text { Fixed } \\
\text { Effects }\end{array}$ & $\begin{array}{l}\text { Random } \\
\text { Effects }^{2}\end{array}$ & OLS $^{1}$ & $\begin{array}{l}\text { LS (self-sel. } \\
\text { Corr.) }^{1}\end{array}$ & $\begin{array}{l}\text { Fixed } \\
\text { Effects }\end{array}$ & $\begin{array}{l}\text { Random } \\
\text { Effects }^{2}\end{array}$ \\
\hline Constant & $\begin{array}{c}3.923 \\
(0.006)\end{array}$ & $\begin{array}{c}3.901 \\
(0.008)\end{array}$ & - & $\begin{array}{c}3.933 \\
(0.022)\end{array}$ & $\begin{array}{c}3.845 \\
(0.006)\end{array}$ & $\begin{array}{c}3.836 \\
(0.015)\end{array}$ & - & $\begin{array}{r}3.773 \\
(0.025)\end{array}$ \\
\hline 1 child & $\begin{array}{l}-0.003 \\
(0.004)\end{array}$ & $\begin{array}{l}-0.004 \\
(0.004)\end{array}$ & $\begin{array}{c}0.001 \\
(0.005)\end{array}$ & $\begin{array}{c}0.001 \\
(0.007)\end{array}$ & $\begin{array}{l}-0.009 \\
(0.004)\end{array}$ & $\begin{array}{l}-0.007 \\
(0.005)\end{array}$ & $\begin{array}{c}0.005 \\
(0.007)\end{array}$ & $\begin{array}{r}0.006 \\
(0.008)\end{array}$ \\
\hline 2 or more children & $\begin{array}{c}0.015 \\
(0.004)\end{array}$ & $\begin{array}{c}0.015 \\
(0.004)\end{array}$ & $\begin{array}{c}0.011 \\
(0.006)\end{array}$ & $\begin{array}{c}0.016 \\
(0.008)\end{array}$ & $\begin{array}{l}-0.021 \\
(0.004)\end{array}$ & $\begin{array}{l}-0.019 \\
(0.005)\end{array}$ & $\begin{array}{c}0.002 \\
(0.008)\end{array}$ & $\begin{array}{c}0.000 \\
(0.010)\end{array}$ \\
\hline Legally married & $\begin{array}{c}0.060 \\
(0.004)\end{array}$ & $\begin{array}{c}0.065 \\
(0.004)\end{array}$ & $\begin{array}{c}0.005 \\
(0.004)\end{array}$ & $\begin{array}{c}0.024 \\
(0.007)\end{array}$ & $\begin{array}{l}-0.010 \\
(0.003)\end{array}$ & $\begin{array}{l}-0.011 \\
(0.004)\end{array}$ & $\begin{array}{c}0.000 \\
(0.004)\end{array}$ & $\begin{array}{l}-0.005 \\
(0.006)\end{array}$ \\
\hline Cohabiting, not married & $\begin{array}{c}0.037 \\
(0.004)\end{array}$ & $\begin{array}{c}0.043 \\
(0.004)\end{array}$ & $\begin{array}{c}0.000 \\
(0.004)\end{array}$ & $\begin{array}{c}0.013 \\
(0.006)\end{array}$ & $\begin{array}{c}0.000 \\
(0.004)\end{array}$ & $\begin{array}{c}0.001 \\
(0.004)\end{array}$ & $\begin{array}{c}0.007 \\
(0.004)\end{array}$ & $\begin{array}{r}0.010 \\
(0.006)\end{array}$ \\
\hline Actual experience & $\begin{array}{c}0.029 \\
(0.001)\end{array}$ & $\begin{array}{c}0.031 \\
(0.001)\end{array}$ & $\begin{array}{c}0.034 \\
(0.001)\end{array}$ & $\begin{array}{c}0.031 \\
(0.002)\end{array}$ & $\begin{array}{c}0.021 \\
(0.001)\end{array}$ & $\begin{array}{c}0.022 \\
(0.001)\end{array}$ & $\begin{array}{c}0.031 \\
(0.001)\end{array}$ & $\begin{array}{c}0.029 \\
(0.002)\end{array}$ \\
\hline Actual exp. squared/100 & $\begin{array}{l}-0.006 \\
(0.000)\end{array}$ & $\begin{array}{l}-0.006 \\
(0.000)\end{array}$ & $\begin{array}{l}-0.005 \\
(0.000)\end{array}$ & $\begin{array}{l}-0.005 \\
(0.000)\end{array}$ & $\begin{array}{l}-0.003 \\
(0.000)\end{array}$ & $\begin{array}{l}-0.003 \\
(0.000)\end{array}$ & $\begin{array}{l}-0.004 \\
(0.000)\end{array}$ & $\begin{array}{l}-0.003 \\
(0.000)\end{array}$ \\
\hline Short education & $\begin{array}{c}0.000 \\
(0.005)\end{array}$ & $\begin{array}{c}0.000 \\
(0.005)\end{array}$ & $\begin{array}{l}-0.177 \\
(0.018)\end{array}$ & $\begin{array}{l}-0.063 \\
(0.012)\end{array}$ & $\begin{array}{c}0.003 \\
(0.004)\end{array}$ & $\begin{array}{c}0.004 \\
(0.004)\end{array}$ & $\begin{array}{l}-0.053 \\
(0.014)\end{array}$ & $\begin{array}{l}-0.012 \\
(0.010)\end{array}$ \\
\hline Medium education & $\begin{array}{c}0.054 \\
(0.004)\end{array}$ & $\begin{array}{c}0.056 \\
(0.004)\end{array}$ & $\begin{array}{l}-0.001 \\
(0.016)\end{array}$ & $\begin{array}{c}0.043 \\
(0.009)\end{array}$ & $\begin{array}{c}0.025 \\
(0.004)\end{array}$ & $\begin{array}{c}0.027 \\
(0.005)\end{array}$ & $\begin{array}{c}0.012 \\
(0.013)\end{array}$ & $\begin{array}{c}0.029 \\
(0.010)\end{array}$ \\
\hline Long education & $\begin{array}{c}0.102 \\
(0.005)\end{array}$ & $\begin{array}{c}0.106 \\
(0.005)\end{array}$ & $\begin{array}{c}0.084 \\
(0.019)\end{array}$ & $\begin{array}{c}0.173 \\
(0.015)\end{array}$ & $\begin{array}{c}0.108 \\
(0.005)\end{array}$ & $\begin{array}{c}0.111 \\
(0.006)\end{array}$ & $\begin{array}{c}0.219 \\
(0.017)\end{array}$ & $\begin{array}{r}0.195 \\
(0.014)\end{array}$ \\
\hline High level salaried & $\begin{array}{c}0.308 \\
(0.005)\end{array}$ & $\begin{array}{c}0.307 \\
(0.005)\end{array}$ & $\begin{array}{c}0.070 \\
(0.007)\end{array}$ & $\begin{array}{c}0.146 \\
(0.012)\end{array}$ & $\begin{array}{c}0.334 \\
(0.007)\end{array}$ & $\begin{array}{c}0.334 \\
(0.007)\end{array}$ & $\begin{array}{c}0.039 \\
(0.010)\end{array}$ & $\begin{array}{c}0.134 \\
(0.016)\end{array}$ \\
\hline Medium level salaried & $\begin{array}{c}0.107 \\
(0.005)\end{array}$ & $\begin{array}{c}0.107 \\
(0.005)\end{array}$ & $\begin{array}{c}0.051 \\
(0.006)\end{array}$ & $\begin{array}{c}0.071 \\
(0.009)\end{array}$ & $\begin{array}{c}0.058 \\
(0.005)\end{array}$ & $\begin{array}{c}0.058 \\
(0.005)\end{array}$ & $\begin{array}{l}-0.027 \\
(0.007)\end{array}$ & $\begin{array}{c}-0.016 \\
(0.010)\end{array}$ \\
\hline Low level salaried & $\begin{array}{l}-0.055 \\
(0.004)\end{array}$ & $\begin{array}{l}-0.055 \\
(0.004)\end{array}$ & $\begin{array}{l}-0.013 \\
(0.006)\end{array}$ & $\begin{array}{l}-0.016 \\
(0.007)\end{array}$ & $\begin{array}{c}0.004 \\
(0.003)\end{array}$ & $\begin{array}{c}0.004 \\
(0.003)\end{array}$ & $\begin{array}{l}-0.028 \\
(0.005)\end{array}$ & $\begin{array}{c}-0.028 \\
(0.006)\end{array}$ \\
\hline Province & $\begin{array}{c}-0.082 \\
(0.003)\end{array}$ & $\begin{array}{c}-0.083 \\
(0.003)\end{array}$ & $\begin{array}{c}-0.044 \\
(0.008)\end{array}$ & $\begin{array}{l}-0.069 \\
(0.008)\end{array}$ & $\begin{array}{l}-0.073 \\
(0.003)\end{array}$ & $\begin{array}{c}-0.073 \\
(0.003)\end{array}$ & $\begin{array}{l}-0.039 \\
(0.009)\end{array}$ & $\begin{array}{c}-0.067 \\
(0.007)\end{array}$ \\
\hline Lambda & - & $\begin{array}{c}0.034 \\
(0.008)\end{array}$ & $\begin{array}{l}-0.110 \\
(0.007)\end{array}$ & $\begin{array}{l}-0.075 \\
(0.029)\end{array}$ & - & $\begin{array}{c}0.010 \\
(0.013)\end{array}$ & $\begin{array}{c}0.015 \\
(0.013)\end{array}$ & $\begin{array}{c}0.025 \\
(0.021)\end{array}$ \\
\hline R square & 0.378 & 0.378 & 0.785 & - & 0.32 & 0.32 & 0.7 & - \\
\hline Scale & - & - & - & 0.277 & - & - & - & 0.227 \\
\hline No. of obs. & 33124 & 33124 & 33124 & 33124 & 26731 & 26731 & 26731 & 26731 \\
\hline
\end{tabular}

Note 1: The LS-estimates are based on the full sample of individuals aged 18-40 years in 1980 and 18-55 years in 1995. Thus, the estimates may include age composition effects as described in Section 5. Alternative LSestimations, not shown here, based on the restricted sample of only 18-40-year-old persons in all years are very close to the results shown in this table.

Note 2: The random effects model is estimated by the GEE-procedure in SAS which uses a ML-estimator, see SAS/STAT Software (1997). The scale parameter is the square root of the normalized Pearson's Chi-square. 
Table 3. Random effects estimation of log hourly wage. 1980-1995. Women (Standard errors in parentheses)

\begin{tabular}{|c|c|c|c|}
\hline & Model 1 & Model 2 & Model 3 \\
\hline Constant & $3.750(0.025)$ & $3.748(0.020)$ & $3.721(0.028)$ \\
\hline 1 child & $0.005(0.009)$ & - & $0.043(0.018)$ \\
\hline 2 or more children & $-0.005(0.010)$ & - & $0.063(0.018)$ \\
\hline Legally married & $-0.007(0.006)$ & $-0.007(0.006)$ & $-0.007(0.006)$ \\
\hline Cohabiting, not married & $0.011(0.006)$ & $0.012(0.006)$ & $0.010(0.006)$ \\
\hline Short education & $0.007(0.010)$ & $0.007(0.010)$ & $-0.011(0.010)$ \\
\hline Medium education & $0.047(0.011)$ & $0.047(0.011)$ & $0.033(0.010)$ \\
\hline Long education & $0.215(0.015)$ & $0.216(0.014)$ & $0.197(0.014)$ \\
\hline High level salaried & $0.135(0.016)$ & $0.136(0.016)$ & $0.133(0.016)$ \\
\hline Medium level salaried & $-0.015(0.010)$ & $-0.015(0.010)$ & $-0.016(0.010)$ \\
\hline Low level salaried & $-0.027(0.006)$ & $-0.026(0.006)$ & $-0.028(0.006)$ \\
\hline Actual experience & $0.028(0.002)$ & $0.028(0.002)$ & \\
\hline Interaction: 0 children & & & $0.039(0.003)$ \\
\hline 1 child & & & $0.030(0.003)$ \\
\hline 2 or more ch. & & & $0.026(0.002)$ \\
\hline Actual exp. squared/100 & $-0.003(0.001)$ & $-0.000(0.000)$ & \\
\hline Interaction: 0 children & & & $-0.007(0.001)$ \\
\hline 1 child & & & $-0.004(0.001)$ \\
\hline 2 or more ch. & & & $-0.003(0.001)$ \\
\hline Years out of labour market & $0.001(0.002)$ & $0.008(0.018)$ & - \\
\hline Years out of.. squared/100 & $0.001(0.001)$ & $0.001(0.001)$ & - \\
\hline Province & $-0.069(0.007)$ & $-0.070(0.007)$ & $-0.067(0.007)$ \\
\hline Lambda & $0.024(0.021)$ & $0.028(0.018)$ & $0.037(0.021)$ \\
\hline Scale & 0.227 & 0.227 & 0.227 \\
\hline No. of obs. & 26731 & 26731 & 26731 \\
\hline
\end{tabular}

Notes: See Table 2.

In Models 1 and 2, we assume that the 'return' to an extra year of employment experience is not affected by the number of children. If we define the 'wage profile' as the hourly wage rate as a function of the woman's age, this means that the wage profile has the same slope for all employed women, irrespective of number of children and of the timing and spacing of non-employment periods. In Model 3, we loosen this assumption by allowing the slope of the 'wage profile' to vary, depending on number of children. According to Model 3, women without children have a significantly higher coefficient to the experience variable than women with 2 or more children. Ignoring the squared experience terms, one extra year of experience increases the hourly wage by 
$3.9 \%$ for women without children, $3.0 \%$ for women with 1 child and $2.6 \%$ for women with 2 or more children. ${ }^{13}$ This indicates that the 'wage profile' is steeper for women without children and young women before they have their first child compared to after the first child is born.

Model 3 does not give any information on the effects of the timing and spacing of children on the wage profiles of mothers. In order to analyse this aspect, we select men and women in the sample who were aged 18-39 years in 1980 and who were observed not to have any children in that year. In 1980, approximately 800 men and 400 women in the sample fulfilled these criteria. These individuals are followed each of the years 1980-1995 and each year we calculate three new variables for those who become mothers during the observation period: Experience before first childbirth, experience between childbirths and experience after the last childbirth recorded in the data. These three variables are included in the wage function in Table 4 . The variable representing 'experience before first child' measures the total accumulated experience for the women with no children (yet). Since the experience coefficients before and after childbirth may also reflect the generally observed curvature of experience profiles, we compare the results for women with parallel estimations of male wage functions.

The results indicate that the wage profiles are steeper for women than for men before the birth of the first child. One explanation may be that women are employed in jobs with lower investments in on-the-job training and therefore, their wages are increasing faster than men's wages in the first years of their labour market career. When the first child is born, the 'return' to one extra year of experience drops considerably for mothers while it increases for fathers. When the last child has been born, the 'wage profile' becomes flatter, also for fathers, probably reflecting that they have become older and that 'wage profiles' generally tend to become flatter over the career.

In order to include the effects of the square terms more precisely, Figure 1 shows the calculated hourly wages for three 'standardized' persons: A person with no children, a person who has one child at the age of 25 and a person who has two children at the age of 25 and 28 . The wage rates for the three 'standardized' women are calculated as the estimated constant term plus the estimated experience effects for a person entering the labour market at the age of 20 and employed on a full-time basis in all years. All other variables assume the value of 0 , thus the person has no formal education beyond compulsory school and is employed as a manual worker in Copenhagen.

\footnotetext{
${ }^{13}$ If the square term effects are included and evaluated at an average experience level of 8 years, the wage effects of one extra year of experience are 3.0,2.5, and $2.2 \%$ for women with 0,1 and 2 or more children, respectively.
} 
Table 4. Random effects estimation of log hourly wage. 1980-1995. Men and women who had no children in 1980 and were aged 18-40 years in 1980. (Standard errors in parentheses)

\begin{tabular}{|c|c|c|}
\hline & Men & Women \\
\hline Constant & $4.030(0.028)$ & $3.816(0.042)$ \\
\hline 1 child & $0.017(0.009)$ & $0.008(0.012)$ \\
\hline 2 or more children & $0.009(0.013)$ & $0.013(0.020)$ \\
\hline Legally married & $-0.001(0.009)$ & $-0.003(0.011)$ \\
\hline Cohabiting, not married & $-0.012(0.008)$ & $0.004(0.010)$ \\
\hline Short education & $-0.027(0.015)$ & $-0.042(0.019)$ \\
\hline Medium education & $0.038(0.015)$ & $0.010(0.021)$ \\
\hline Long education & $0.166(0.022)$ & $0.163(0.026)$ \\
\hline High level salaried & $0.146(0.019)$ & $0.126(0.027)$ \\
\hline Medium level salaried & $0.075(0.015)$ & $-0.030(0.017)$ \\
\hline Low level salaried & $-0.020(0.011)$ & $-0.030(0.013)$ \\
\hline Exp. before $1^{\text {st }}$ childbirth & $0.024(0.003)$ & $0.033(0.004)$ \\
\hline Experience before $1^{\text {st }}$ childbirth squared/10 & $-0.004(0.001)$ & $-0.006(0.001)$ \\
\hline Exp. between childbirths & $0.036(0.006)$ & $0.014(0.073)$ \\
\hline Experience between childbirths squared/10 & $-0.019(0.007)$ & $0.026(0.010)$ \\
\hline Exp. after last childbirth & $0.017(0.004)$ & $0.012(0.005)$ \\
\hline Experience after last childbirth squared/10 & $-0.002(0.003)$ & $0.010(0.007)$ \\
\hline Province & $-0.067(0.010)$ & $-0.070(0.011)$ \\
\hline Lambda & $-0.171(0.029)$ & $0.000(0.032)$ \\
\hline Scale & 0.268 & 0.222 \\
\hline No. of obs. & 13006 & 6963 \\
\hline
\end{tabular}

Figure 1 shows that wages of women increase slower after first childbirth, compared to the wage growth for non-mothers, even if mothers work full time immediately after childbirth, i.e. had no loss of experience because of childbirth. However, due to the effects of the squared terms, this effect of childbirth does not seem to be permanent. After some years, the wages of mothers seem to catch-up with that of non-mothers, with a 'break-even' in the late thirties. Thus, looking more closely at the experience profiles before and after childbirth confirms the results in the previous analyses that there is no permanent negative effect for Danish mothers from having children, except from lack of experience accumulation for women who actually leave the labour market. 
Figure 1. The calculated hourly wage rate for three 'standardized' men and women with 0,1 and 2 children

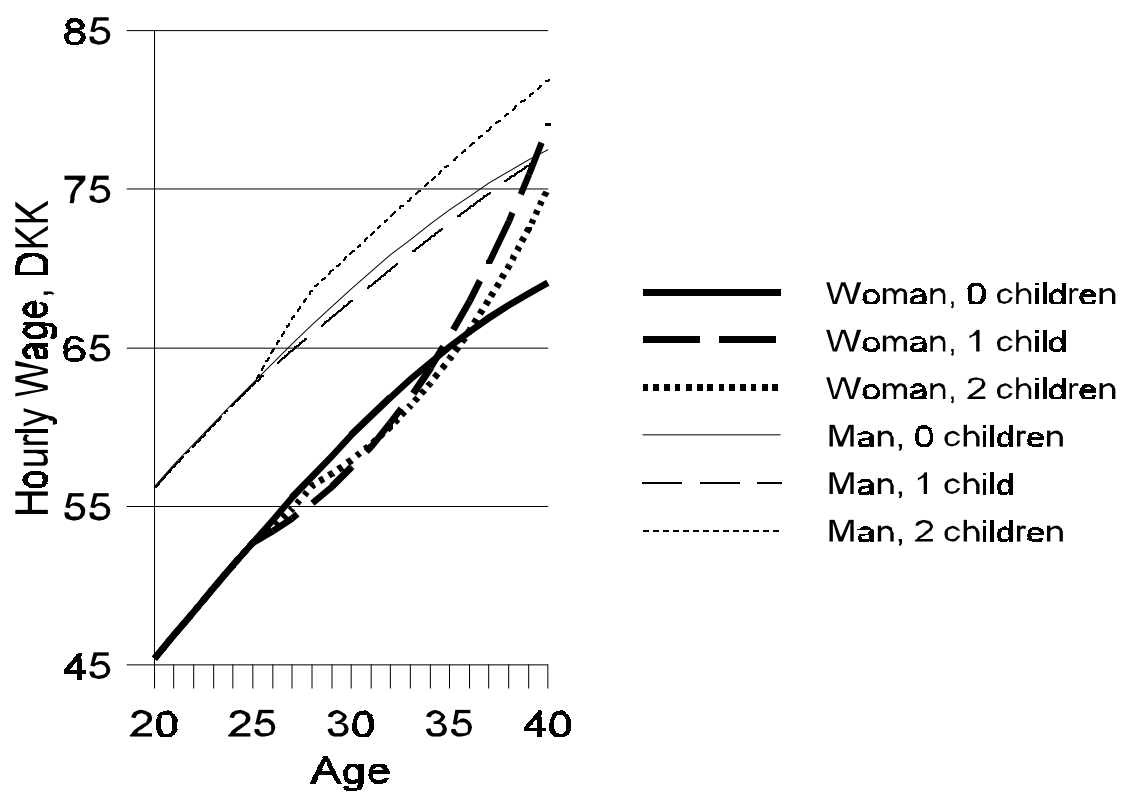

Note: The calculated hourly wages are based on the estimates presented in Table 4 . The concept of a 'standardized' person is described in the text.

In order to evaluate the more permanent wage effects due to loss of accumulation of experience during the childbirth period, we have calculated the predicted wage rates based on the estimations in Table 4 for a 'standardized woman' with two children taking 0,1 and 2 years' leave from the labour market for each child born. These results are shown in Figure 2. As expected, the wage profiles for women taking one or two years' leave from the labour market when they give birth to a child show a considerable wage loss compared to the almost hypothetical woman who does not take a leave period. On average, Danish women spend 50 weeks or about one year out of the labour market per child born, see Datta Gupta and Smith (2000). Based on the results in Table 4 and Figure 2, this one year leave period per child born implies, evaluated at the age of 40, an hourly wage loss of about $7 \% .{ }^{14}$ Still, Figure 2 indicates that even women with more children and more years of leave per child born seem to catch-up with non-mothers with respect to their hourly wages although the catch-up process may take several years.

\footnotetext{
${ }^{14}$ Based on the estimation results in Table 4, the calculated hourly wage rate at the age of 40 for a 'standardized woman' with 2 children and no leave period is DKK 75.14, while the corresponding figure for a 'standardized woman' with 1 year (2 years) leave per child is DKK 70.63 (DKK 66.86).
} 
Figure 2. The calculated hourly wage rate for a 'standardized' non-mother and a mother with 2 children who takes 0,1 and 2 years leave from the labour market per child born.
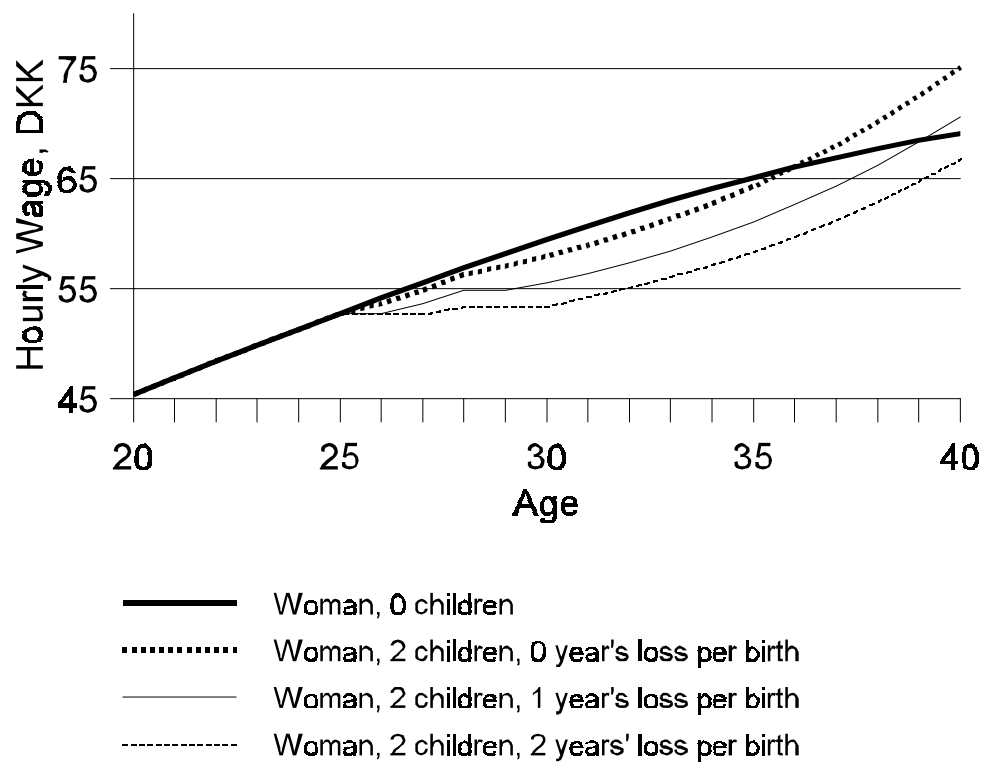

Note: See Figure 1.

Thus, the overall conclusion from the analyses in this section is that childbirth does have a negative effect on the wages of mothers, but the wage effect is not a permanent one. The longer the maternal leave period, the more years it takes a mother to catch up with the wage level of nonmothers but if the mother returns to work after her last child is born, she might reach the nonmother wage level, ceteris paribus. However, as discussed in Section 2, the general coverage of maternal leave schemes in Denmark might have negative wage effects on all potential mothers, i.e. young women and women who do not intend to become mothers may face statistical discrimination. As indicated by the constant terms in Table 4, the starting wages for men are considerably higher than for women, mothers as well as non-mothers. The wage profiles in Figure 1 show that this tendency continues over the career. Although there may be many other explanations of the gender wage gap, the analyses in this study cannot reject the hypothesis that the effect of children, career interruptions etc. influence the wage level of all women, instead of being an effect only applying to those women who become mothers. 


\section{Conclusion}

In this paper, we have analysed the effect of children on the earnings capacity of women. In previous studies for some countries, for instance the UK and the US, the presence and/or number of children have been found to have negative effects on mothers' wages. However, other studies have found that mothers do not have lower wages than women without children. We use a panel data set of $0.5 \%$ of the Danish population covering each of the years 1980-1995. Thus and unlike previous cross-section studies, we are able to control for unobserved time constant heterogeneity. Our results confirm earlier Danish studies that children do not seem to have a negative effect on their mother's wages, holding experience constant. In fact, the significantly negative effects of children and marriage on women's wages found in OLS and LS estimations disappear when we use a panel data estimator controlling for unobserved heterogeneity and self-selectivity. This result is robust to the specification of children as either the presence of children or the number of children.

We also investigate whether children affect mothers' earnings capacity when we control for missing human capital accumulations due to periods out of the labour market. The results show that for the "standardized" woman, the birth of a child does indeed lead to a slower wage growth compared to the wage growth of non-mothers. However, the effect is only temporary and mothers seem to catch up slowly with non-mothers after the age of about 35 .

We therefore conclude that neither the presence nor the number of children have significant or lasting effects on women's wages in Denmark, holding experience constant. Human capital theories of the depreciation of women's labour market potential during career interruptions are supported although the negative effects are small seen over the entire career perspective. The finding that the main effect of children seems to be loss of human capital accumulation during the childbirth period suggests that there is a need for more innovative labour market leave schemes based on negotiations between individuals and their employers allowing for some work time during leaves. For example, flexible work-time scheduling, part-time work, home-based work or work-sharing during leaves may be solutions to the problems of depreciation of human capital and the loss of human capital accumulation associated with leave periods. A final policy prescription that could narrow the gender gap in earnings would be the extension of paternal leave schemes. 


\section{References}

Albrecht, J.W., P.-E. Edin, M. Sundstrøm, S.B. Wroman (1999), Career interruptions and subsequent earnings, Journal of Human Resources 34, no. 2, 294-311.

Browning, M. (1992), Children and household economic behavior, Journal of Economic Literature XXX, no. 3, 1434-1475.

Datta Gupta, N., R. Oaxaca and N. Smith (1998), Wage dispersion, public sector wages and the stagnating Danish gender wage gap, CLS working paper 98:18, University of Aarhus and Aarhus School of Business.

Datta Gupta, N., R. Oaxaca and N. Smith (1999), The Danish gender wage gap and wage determination in the public and private sectors, forthcoming in Gender and the Labour Market: Econometric Evidence on Obstacles in Achieving Gender Equality, (eds.) S. Gustafsson and D. Meulders, AEA Macmillan Series.

Datta Gupta, N. and N. Smith (2000), Children and Career Interruptions: The Family Gap In Denmark, CLS working paper 2000:18, University of Aarhus and Aarhus School of Business.

Heckman, J.J. (1979), Sample selection bias as a specification error. Econometrica 47, 153-162.

Joshi, H., P. Paci, and J. Waldfogel (1999), The wages of motherhood: better or worse?, Cambridge Journal of Economics, 23, 543-564.

Korenman, S. and D. Neumark(1991), Does marriage really make men more productive?, Journal of Human Resources 26, 282-307.

Korenman, S. and D. Neumark (1992), Marriage, motherhood and wages, Journal of Human Resources 27, 233-55.

Mincer, J. and S. Polachek (1974), Family investments in human capital: earnings of women, Journal of Political Economy 82, 576-608.

Naur, M., M. Rosholm and N. Smith (1994), "Wage differentials between men and women in the 1980s", Nationalфkonomisk Tidsskrift, 132, 260-85. 
Naur M. and N. Smith (1997), Cohort differences in the gender wage gap, in I. Persson and C. Jonung (eds.), Women's Work and Wages, Routledge.

OECD (1996), Employment Outlook, Paris.

Rosenfeld, R. and A.L. Kalleberg (1991), Gender inequality in the labour market, in Acta Sociologica 34, 207-225.

Rosholm, M. and N. Smith (1996), The Danish gender wage gap in the 1980s: a panel data study. Oxford Economic Papers 48, 254-79.

Ruhm, C. (1998), The economic consequences of parental leave mandates: lessons from Europe, Quarterly Journal of Economics 113, 285-317.

SAS/STAT Software (1997), Changes and enhancement through Release 6.12, Cary, USA.

Vella, F. (1998), Estimating models with sample selection bias: a survey, Journal of Human Resources, 33, No. 1, 127-169.

Verbeek, M. and T. Nijman (1992), Testing for selectivity bias in panel data models, International Economic Review, 33, No. 3, 681-703.

Waldfogel, J. (1998a), The family gap for young women in the United States and Britain: can maternity leave make a difference?, Journal of Labor Economics 16, 505-545.

Waldfogel, J. (1998b), Understanding the 'family gap' in pay for women with children, Journal of Economic Perspectives, 12, no. 1, 137-56.

Westergård-Nielsen, N. (1988), Timeløn, kompensationsgrad, erhvervserfaring og uddannelse. Studies in Labour Market Dynamics, Working Paper 88-3. Aarhus School of Business, Denmark. 


\section{APPENDIX}

Table A1. Sample means by gender. Pooled sample and the years 1980 and 1995. Standard deviations in parentheses.

\begin{tabular}{|c|c|c|c|c|c|c|}
\hline & \multicolumn{2}{|c|}{ 1980-1995 } & \multicolumn{2}{|c|}{1980} & \multicolumn{2}{|c|}{1995} \\
\hline & Men & Women & Men & Women & Men & Women \\
\hline $\begin{array}{l}\text { Hourly wage rate } \\
\text { (DKK, } 1980 \text { prices) }\end{array}$ & $\begin{array}{c}74.26 \\
(27.72)\end{array}$ & $\begin{array}{c}57.72 \\
(15.88)\end{array}$ & $\begin{array}{c}65.64 \\
(17.28)\end{array}$ & $\begin{array}{c}51.43 \\
(12.67)\end{array}$ & $\begin{array}{c}78.23 \\
(31.90)\end{array}$ & $\begin{array}{c}61.42 \\
(18.01)\end{array}$ \\
\hline One child & $\begin{array}{c}0.22 \\
(0.41)\end{array}$ & $\begin{array}{c}0.24 \\
(0.42)\end{array}$ & $\begin{array}{c}0.18 \\
(0.39)\end{array}$ & $\begin{array}{c}0.23 \\
(0.42)\end{array}$ & $\begin{array}{c}0.23 \\
(0 . .42)\end{array}$ & $\begin{array}{c}0.23 \\
(0.42)\end{array}$ \\
\hline Two or more children & $\begin{array}{c}0.55 \\
(0.50)\end{array}$ & $\begin{array}{c}0.61 \\
(0.49)\end{array}$ & $\begin{array}{c}0.38 \\
(0.48)\end{array}$ & $\begin{array}{c}0.45 \\
(0.50)\end{array}$ & $\begin{array}{c}0.64 \\
(0.48)\end{array}$ & $\begin{array}{c}0.69 \\
(0.46)\end{array}$ \\
\hline Child $0-2$ years old & $\begin{array}{c}0.14 \\
(0.35)\end{array}$ & $\begin{array}{c}0.13 \\
(0.33)\end{array}$ & $\begin{array}{c}0.19 \\
(0.40)\end{array}$ & $\begin{array}{c}0.19 \\
(0.39)\end{array}$ & $\begin{array}{c}0.10 \\
(0.30)\end{array}$ & $\begin{array}{c}0.10 \\
(0.30)\end{array}$ \\
\hline Number of children & $\begin{array}{l}1.49 \\
(1.07)\end{array}$ & $\begin{array}{l}1.68 \\
(1.02)\end{array}$ & $\begin{array}{c}0.93 \\
(0.90)\end{array}$ & $\begin{array}{l}1.13 \\
(0.87)\end{array}$ & $\begin{array}{l}1.51 \\
(0.72)\end{array}$ & $\begin{array}{c}1.60 \\
(0.64)\end{array}$ \\
\hline Potential experience, years & $\begin{array}{l}16.33 \\
(8.09)\end{array}$ & $\begin{array}{l}16.38 \\
(8.44)\end{array}$ & $\begin{array}{l}11.61 \\
(5.49)\end{array}$ & $\begin{array}{l}11.58 \\
(5.75)\end{array}$ & $\begin{array}{l}19.92 \\
(9.67)\end{array}$ & $\begin{array}{l}19.75 \\
(9.80)\end{array}$ \\
\hline Actual experience, years & $\begin{array}{l}12.12 \\
(7.20)\end{array}$ & $\begin{array}{l}10.22 \\
(6.27)\end{array}$ & $\begin{array}{r}7.96 \\
(4.65)\end{array}$ & $\begin{array}{l}6.52 \\
(3.92)\end{array}$ & $\begin{array}{l}15.00 \\
(9.01)\end{array}$ & $\begin{array}{l}12.82 \\
(7.65)\end{array}$ \\
\hline Years out of the labour market & $\begin{array}{c}4.21 \\
(4.06)\end{array}$ & $\begin{array}{l}6.16 \\
(5.49)\end{array}$ & $\begin{array}{c}3.66 \\
(2.98)\end{array}$ & $\begin{array}{l}5.06 \\
(4.23)\end{array}$ & $\begin{array}{l}4.92 \\
(5.02)\end{array}$ & $\begin{array}{l}6.93 \\
(6.19)\end{array}$ \\
\hline Length of education, years & $\begin{array}{c}2.65 \\
(2.44)\end{array}$ & $\begin{array}{c}2.56 \\
(2.27)\end{array}$ & $\begin{array}{c}2.41 \\
(2.31)\end{array}$ & $\begin{array}{c}2.13 \\
(2.16)\end{array}$ & $\begin{array}{c}2.76 \\
(2.48)\end{array}$ & $\begin{array}{c}2.87 \\
(2.34)\end{array}$ \\
\hline $\begin{array}{l}\text { Occupational categories: } \\
\text { High level non-manual worker }\end{array}$ & $\begin{array}{c}0.14 \\
(0.35)\end{array}$ & $\begin{array}{c}0.05 \\
(0.21)\end{array}$ & $\begin{array}{c}0.11 \\
(0.32)\end{array}$ & $\begin{array}{c}0.04 \\
(0.19)\end{array}$ & $\begin{array}{c}0.14 \\
(0.35)\end{array}$ & $\begin{array}{c}0.05 \\
(0.22)\end{array}$ \\
\hline Medium level non-manual & $\begin{array}{c}0.14 \\
(0.35)\end{array}$ & $\begin{array}{c}0.17 \\
(0.37)\end{array}$ & $\begin{array}{r}0.12 \\
(0.33)\end{array}$ & $\begin{array}{c}0.14 \\
(0.35)\end{array}$ & $\begin{array}{c}0.15 \\
(0.35)\end{array}$ & $\begin{array}{c}0.18 \\
(0.38)\end{array}$ \\
\hline Low level non-manual & $\begin{array}{c}0.17 \\
(0.38)\end{array}$ & $\begin{array}{c}0.44 \\
(0.50)\end{array}$ & $\begin{array}{c}0.21 \\
(0.41)\end{array}$ & $\begin{array}{c}0.47 \\
(0.50)\end{array}$ & $\begin{array}{c}0.14 \\
(0.35)\end{array}$ & $\begin{array}{c}0.41 \\
(0.49)\end{array}$ \\
\hline Manual skilled worker & $\begin{array}{c}0.22 \\
(0.41)\end{array}$ & $\begin{array}{c}0.02 \\
(0.14)\end{array}$ & $\begin{array}{r}0.26 \\
(0.44)\end{array}$ & $\begin{array}{c}0.02 \\
(0.13)\end{array}$ & $\begin{array}{r}0.20 \\
(0.40)\end{array}$ & $\begin{array}{r}0.03 \\
(0.16)\end{array}$ \\
\hline Manual unskilled worker & $\begin{array}{l}0.25 \\
(0.43)\end{array}$ & $\begin{array}{c}0.25 \\
(0.43)\end{array}$ & $\begin{array}{l}0.26 \\
(0.44)\end{array}$ & $\begin{array}{c}0.28 \\
(0.45)\end{array}$ & $\begin{array}{r}0.26 \\
(0.44)\end{array}$ & $\begin{array}{c}0.23 \\
(0.42)\end{array}$ \\
\hline Region (outside Copenhagen) & $\begin{array}{r}0.66 \\
(0.47)\end{array}$ & $\begin{array}{c}0.63 \\
(0.48)\end{array}$ & $\begin{array}{c}0.65 \\
(0.48)\end{array}$ & $\begin{array}{c}0.63 \\
(0.48)\end{array}$ & $\begin{array}{r}0.67 \\
(0.47)\end{array}$ & $\begin{array}{c}0.64 \\
(0.48)\end{array}$ \\
\hline Owner of residence & $\begin{array}{c}0.75 \\
(0.43)\end{array}$ & $\begin{array}{c}0.57 \\
(0.50)\end{array}$ & $\begin{array}{c}0.59 \\
(0.49)\end{array}$ & $\begin{array}{c}0.15 \\
(0.36)\end{array}$ & $\begin{array}{c}0.56 \\
(0.50)\end{array}$ & $\begin{array}{c}0.38 \\
(0.49)\end{array}$ \\
\hline Legally married & $\begin{array}{c}0.54 \\
(0.50)\end{array}$ & $\begin{array}{c}0.58 \\
(0.49)\end{array}$ & $\begin{array}{c}0.53 \\
(0.50)\end{array}$ & $\begin{array}{c}0.58 \\
(0.49)\end{array}$ & $\begin{array}{c}0.53 \\
(0.50)\end{array}$ & $\begin{array}{c}0.58 \\
(0.49)\end{array}$ \\
\hline Cohabiting, not married & $\begin{array}{c}0.17 \\
(0.38)\end{array}$ & $\begin{array}{c}0.19 \\
(0.39)\end{array}$ & $\begin{array}{c}0.16 \\
(0.37)\end{array}$ & $\begin{array}{c}0.18 \\
(0.38)\end{array}$ & $\begin{array}{c}0.17 \\
(0.38)\end{array}$ & $\begin{array}{c}0.18 \\
(0.39)\end{array}$ \\
\hline Wealth (DKK 1,000, 1980 prices) & $\begin{array}{c}36.81 \\
(150.84)\end{array}$ & $\begin{array}{c}11.43 \\
(82.19)\end{array}$ & $\begin{array}{c}41.20 \\
(158.28)\end{array}$ & $\begin{array}{c}0.96 \\
(52.29)\end{array}$ & $\begin{array}{c}29.44 \\
(150.96)\end{array}$ & $\begin{array}{c}13.07 \\
(91.36)\end{array}$ \\
\hline $\begin{array}{l}\text { Non wage income } \\
\text { (DKK 1,000, } 1980 \text { prices) }\end{array}$ & $\begin{array}{r}9.60 \\
(22.49)\end{array}$ & $\begin{array}{c}5.68 \\
(11.98)\end{array}$ & $\begin{array}{r}9.32 \\
(15.08)\end{array}$ & $\begin{array}{c}3.78 \\
(10.40)\end{array}$ & $\begin{array}{c}9.38 \\
(23.17)\end{array}$ & $\begin{array}{c}7.97 \\
(14.66)\end{array}$ \\
\hline Lambda (inverse Mill's ratio) & $\begin{array}{r}0.20 \\
(0.26)\end{array}$ & $\begin{array}{c}0.30 \\
(0.25)\end{array}$ & $\begin{array}{c}0.26 \\
(0.23)\end{array}$ & $\begin{array}{c}0.50 \\
(0.29)\end{array}$ & $\begin{array}{c}0.22 \\
(0.30)\end{array}$ & $\begin{array}{c}0.26 \\
(0.27)\end{array}$ \\
\hline Number of observations & 35078 & 28578 & 1885 & 1291 & 2655 & 2328 \\
\hline
\end{tabular}


Table A2. Random effects estimation of log hourly wage, 1980-1995. (Standard errors in parentheses)

\begin{tabular}{|c|c|c|c|}
\hline & & Women & \\
\hline Constant & $\begin{array}{c}3.776 \\
(0.024)\end{array}$ & $\begin{array}{c}3.773 \\
(0.025)\end{array}$ & $\begin{array}{r}3.772 \\
(0.025)\end{array}$ \\
\hline Number of children & $\begin{array}{c}-0.007 \\
(0.007)\end{array}$ & - & - \\
\hline No. of children squared & $\begin{array}{c}0.003 \\
(0.002)\end{array}$ & - & - \\
\hline 1 child & - & $\begin{array}{c}0.016 \\
(0.008)\end{array}$ & $\begin{array}{r}0.008 \\
(0.009)\end{array}$ \\
\hline 2 or more children & - & $\begin{array}{r}0.000 \\
(0.010)\end{array}$ & $\begin{array}{r}0.002 \\
(0.010)\end{array}$ \\
\hline $\begin{array}{l}\text { Youngest child } \\
0-2 \text { years }\end{array}$ & - & - & $\begin{array}{l}-0.003 \\
(0.005)\end{array}$ \\
\hline Legally married & $\begin{array}{c}-0.005 \\
(0.006)\end{array}$ & $\begin{array}{r}-0.005 \\
(0.006)\end{array}$ & $\begin{array}{l}-0.005 \\
(0.006)\end{array}$ \\
\hline Cohabiting, not married & $\begin{array}{c}0.010 \\
(0.006)\end{array}$ & $\begin{array}{r}0.010 \\
(0.006)\end{array}$ & $\begin{array}{r}0.010 \\
(0.006)\end{array}$ \\
\hline Actual experience & $\begin{array}{c}0.028 \\
(0.002)\end{array}$ & $\begin{array}{c}0.029 \\
(0.002)\end{array}$ & $\begin{array}{r}0.029 \\
(0.002)\end{array}$ \\
\hline Actual exp. squared/100 & $\begin{array}{c}-0.003 \\
(0.000)\end{array}$ & $\begin{array}{l}-0.003 \\
(0.000)\end{array}$ & $\begin{array}{l}-0.003 \\
(0.000)\end{array}$ \\
\hline Short education & $\begin{array}{c}-0.011 \\
(0.010)\end{array}$ & $\begin{array}{r}-0.012 \\
(0.010)\end{array}$ & $\begin{array}{r}-0.012 \\
(0.010)\end{array}$ \\
\hline Medium education & $\begin{array}{c}0.030 \\
(0.010)\end{array}$ & $\begin{array}{c}0.029 \\
(0.010)\end{array}$ & $\begin{array}{r}0.029 \\
(0.010)\end{array}$ \\
\hline Long education & $\begin{array}{c}0.195 \\
(0.014)\end{array}$ & $\begin{array}{c}0.195 \\
(0.014)\end{array}$ & $\begin{array}{c}0.196 \\
(0.014)\end{array}$ \\
\hline High level salaried & $\begin{array}{c}0.135 \\
(0.016)\end{array}$ & $\begin{array}{c}0.134 \\
(0.016)\end{array}$ & $\begin{array}{r}0.134 \\
(0.016)\end{array}$ \\
\hline Medium level salaried & $\begin{array}{r}-0.016 \\
(0.010)\end{array}$ & $\begin{array}{l}-0.016 \\
(0.010)\end{array}$ & $\begin{array}{l}-0.016 \\
(0.010)\end{array}$ \\
\hline Low level salaried & $\begin{array}{l}-0.027 \\
(0.006)\end{array}$ & $\begin{array}{l}-0.028 \\
(0.006)\end{array}$ & $\begin{array}{l}-0.028 \\
(0.006)\end{array}$ \\
\hline Province & $\begin{array}{l}-0.068 \\
(0.007)\end{array}$ & $\begin{array}{l}-0.067 \\
(0.007)\end{array}$ & $\begin{array}{l}-0.067 \\
(0.007)\end{array}$ \\
\hline Lambda & $\begin{array}{c}0.024 \\
(0.021)\end{array}$ & $\begin{array}{c}0.025 \\
(0.021)\end{array}$ & $\begin{array}{c}0.026 \\
(0.021)\end{array}$ \\
\hline Scale & 0.227 & 0.227 & 0.227 \\
\hline No. of obs. & 26731 & 26731 & 26731 \\
\hline
\end{tabular}




\section{IZA Discussion Papers}

\section{No Author(s)}
171 C. Dustmann
F. Windmeijer
172
D. Card

173

174

175

176

177 B. R. Chiswick

G. Repetto

178 R. Euwals

M. Ward

179 E. Wasmer

P. Weil

180 T. K. Bauer

I. N. Gang

181 E. Wasmer

Y. Zenou

182 M. Fertig

C. M. Schmidt

183 M. Fertig

C. M. Schmidt

184 M. Corak

B. Gustafsson

T. Österberg

185 H. Bonin

K. F. Zimmermann
Titel

Area

Date

Wages and the Demand for Health - A Life Cycle

5

Analysis

Reforming the Financial Incentives of the Welfare

System

Timing, Togetherness and Time Windfalls

5

$7 / 00$

Does Money Illusion Matter? An Experimental Approach

Self-Employment and Earnings among HighSkilled Immigrants in the United States

Industrial Relations and the Wage Differentials

between Skilled and Unskilled Blue-Collar

Workers within Establishments: An Empirical

Analysis with Data of Manufacturing Firms

Immigrant Adjustment in Israel: Literacy and

Fluency in Hebrew and Earnings

The Renumeration of British Academics

5

$7 / 00$

The Macroeconomics of Labor and Credit Market Imperfections

Sibling Rivalry in Educational Attainment:

The German Case

Space, Search and Efficiency

$8 / 00$

$8 / 00$

Discretionary Measures of Active Labor Market

Policy: The German Employment Promotion Reform in Perspective

Aggregate-Level Migration Studies as a Tool for 1

Forecasting Future Migration Streams

$8 / 00$

Intergenerational Influences on the Receipt of

3

$8 / 00$

Unemployment Insurance in Canada and Sweden

The Post-Unification German Labor Market

4

$8 / 00$ 
A. S. Kalwij

The Myth of Worksharing

A. Zaidi

Is Unemployment Really Scarring? Effects of 
204 G. S. Epstein

205 A. L. Booth

M. Francesconi

J. Frank

206 C. M. Schmidt

R. Baltussen

R. Sauerborn

207

C. M. Schmidt

208

J. Hartog

R. Winkelmann

209 M. Barbie

M. Hagedorn

A. Kaul

210 T. J. Dohmen

211 A. van Soest

M. Das

X. Gong

212 X. Gong

A. van Soest

P. Zhang

213 X. Gong

A. van Soest

E. Villagomez

214 X. Gong

A. van Soest

215 J. Ermisch

M. Francesconi

216 F. Büchel

217 J. Hansen

R. Wahlberg

218 C. Dustmann

A. van Soest
Labor Market Interactions Between Legal and

1

$10 / 00$

Illegal Immigrants

Temporary Jobs: Stepping Stones or Dead Ends? 1

$10 / 00$

The Evaluation of Community-Based Interventions: Group-Randomization, Limits and

$10 / 00$

Alternatives

Arbeitsmarktpolitische Maßnahmen und ihre

6

$10 / 00$

Evaluierung: eine Bestandsaufnahme

Dutch Migrants in New Zealand:

1

$10 / 00$

Did they Fare Well?

Dynamic Effciency and Pareto Optimality in a

$10 / 00$ Security

Housing, Mobility and Unemployment

$11 / 00$

A Structural Labour Supply Model with

5

$11 / 00$ Nonparametric Preferences

Sexual Bias and Household Consumption: A

Semiparametric Analysis of Engel Curves in Rural China

Mobility in the Urban Labor Market: A Panel Data

$11 / 00$ Analysis for Mexico

5

$11 / 00$

Mamily Structu

The Effect of Parents' Employment on Children's

Educational Attainment

5

$11 / 00$

The Effects of Overeducation on Productivity in Germany - The Firms' Viewpoint

5

$11 / 00$

Occupational Gender Composition and

Wages in Sweden

5

$11 / 00$

Parametric and Semiparametric Estimation in

1

$11 / 00$ Models with Misclassified Categorical Dependent Variables 
220 W. A. Cornelius

E. A. Marcelli

221

C. Grund

222 W.P.M. Vijverberg

223 M. Rosholm

M. Svarer

J. Schwarze

L. Modesto

J. P. Thomas

P. A. Puhani

227

L. Locher
G. Brunello

S. Comi

C. Lucifora
R. Coimbra

T. Lloyd-Braga

L. Modesto

230

L. Modesto

231

G. Saint-Paul

E. Bardasi

M. Francesconi

233 C. Dustmann

C. M. Schmidt
The Changing Profile of Mexican Migrants to the United States: New Evidence from California and Mexico

Wages as Risk Compensation in Germany
$12 / 00$

$12 / 00$

$12 / 00$

Matching Model

Using Panel Data on Income Satisfaction to

An Analysis of Labour Adjustment Costs in Unionized Economies

On the Identification of Relative Wage Rigidity

Dynamics: A Proposal for a Methodology on Cross-Section Data and Empirical Evidence for Poland in Transition

Immigration from the Eastern Block and the former Soviet Union to Israel: Who is coming when?

The College Wage Gap in 10 European

\section{Fluctuations} and Earnings: An Empirical Study for Portugal 

of Labor Income Risk and Car Insurance in the UK 1969-95 the 1990s

244 S. M. Fuess, Jr. M. Millea

Pay and Productivity in a Corporatist Economy: 
